\title{
LEAN ORGANIZATIONAL CULTURE AS AN EXAMPLE OF A POSITIVE ORGANIZATIONAL CULTURE
}

\author{
Piotr Walentynowicz \\ Organization and Management Institute, Management Department, \\ University of Gdansk, Poland, \\ e-mail: p.walentynowicz@wzr.ug.edu.pl
}

\begin{abstract}
In this article the attributes of Lean organizational culture, as an example of a positive organizational culture, are presented. It accompanies applying the concept of Lean Management on a high professional level in a company. An additional goal of the article is to describe the ways of this culture's creation in a company, together with the author's original tool to measure it. As a lot of empirical research proves, Lean Management and thus Lean organizational culture positively contribute to the increase of competitiveness level of a contemporary enterprise and its economic and financial performance.
\end{abstract}

Keywords: Lean organizational culture, Lean Management, attributes of Lean culture, Lean culture measurement

Paper type: Conceptual paper

\section{Introduction}

The inspiration for writing this article was the reading experience of article titled "Positive potential of an organization as a determining factor of the company's success. The case of Poland and France" written by Haffer and Glińska - Newes (2013). In this article, the authors present the results of empirical research on relationship between the positive potential of the organization and its components (inter alia the positive organizational culture) and development of the company and superior results of its performance. Under the influence of this publication, the author realized that a good example of a positive culture of an organization is a Lean organizational culture. In PPO conception, positive organizational culture is defined as ,,a set of dominant norms and values" understood in a positive way from the point of view of the objectives and mechanisms of modern company's performance (Stankiewicz, 2010).

Moreover, the issue of Lean organizational culture while being so interesting is not widespread in Polish literature so far. 
LEAN

ORGANIZATIONAL CULTURE

Piotr Walentynowicz
Therefore, the main objective of this article is to present Lean organizational culture's attributes accompanying the application of the concept of Lean Management [1] in the enterprise on a high level of professionalism, while the secondary objective - is a presentation of the ways of creating this culture with the copyright (proprietary) tool to measure it.

The thesis that without creation of the appropriate organizational culture, the efficient implementation of Lean Managament (as well as the other new pro-effective conceptions of management) is impossible lies at the foundation of the conducted deliberations (Kotter, Heskett,1992; Balle, Balle 2012; Skalik, 2012; Irani, Beskese, Love, 2012). The growing popularity of this phenomenon in practice and thoughts arising from the author's reading of the literature on Lean Management, multiple seminars and training courses on the subject and own empirical research had a huge impact on development of this study [2].

\section{The essence of Lean organizational culture}

While analyzing the features of Lean organizational culture it should be noticed that on the basis of organizational cultures' distinction in terms of definition, level of popularizing and depth of anchoring, the Lean organizational culture is an example of strong culture. In particular cases, dependently from: the level of being convinced to the concept of Lean Management by the organization's members, time of its usage and the range of its application in a company, the strenght of this culture can be different. However, as a showcase within the pattern the members of the organization are striven for absolute subordination of its principles. With the extend that it is done in more voluntary than forced way with help of positive example (particularly from part of the superiors), broadly spread training of organizational's members, their gradual validation and transferring the icreasing responsibility for the effects of their performance (also in a collective form) and by learning the new style of acting in practice. The employees who do not want to subordinate to the new rules are removed from the organization. Cz. Sikorski underlines that "only some of stong organizational cultures can be recognised as desirable from the point of view of organization management" (Sikorski, 2006, p. 15). The Lean organization culture should be included into such cultures which together with its expressiveness, rigorism and stiffness, contains such positive aspects of its members' thinking and performing (inter alia positive attitude towards the changes and novelty, propagating collective work, participating and leadership style of management, first-rate role of customer's requirements, emphasis on constant learning, correction of the results of organization functioning and its development) so it should be evaluated as required from the point of view of contemporary market demands (particularly in production companies).

While comparing other types of organizational cultures with a model of Lean organizational culture it should be arrived at the conclusion that even if in some 
of the previous models there are some features similar with Lean organizational culture type appearing but this type of culture is a new, specific one (Jenei at al., 2011). Regarding the quantity limits of this article, only the outline of this analysis was presented by the author in Table 1.

\begin{tabular}{|c|c|c|}
\hline $\begin{array}{l}\text { Author of } \\
\text { classification }\end{array}$ & Type of organiational culture & $\begin{array}{l}\text { Level of accordance with } \\
\text { Lean organizational } \\
\text { culture }\end{array}$ \\
\hline \multirow{2}{*}{ C. Sathe } & Strong & Big \\
\hline & Weak & Small \\
\hline \multirow{2}{*}{$\begin{array}{l}\text { Cz. Sikorski, } \\
\text { M. Czerska }\end{array}$} & low tolerance of uncertainty (pro-effective) & Small \\
\hline & high tolerance of uncertainty (pro-effective) & Big \\
\hline \multirow{2}{*}{$\begin{array}{l}\text { L. Zbiegień- } \\
\text {-Maciąg }\end{array}$} & Positive & Big \\
\hline & Negative & None \\
\hline \multirow{2}{*}{$\begin{array}{l}\text { J. Kotter and } \\
\text { J. Hesket }\end{array}$} & proinnovative (flexible) & Big \\
\hline & conservative (stiff) & Small \\
\hline \multirow{4}{*}{$\begin{array}{l}\text { R. Harrisona and } \\
\text { Ch. Chandy'ego }\end{array}$} & "power" & None \\
\hline & "role" & Small \\
\hline & "tasks" & Partial \\
\hline & "units" & Small \\
\hline \multirow{4}{*}{$\begin{array}{l}\text { T.E. Deala and } \\
\text { A.A. Kennedyego }\end{array}$} & "tough" (individualists) & None \\
\hline & "gamblers" ("work hard and enjoy") & Small \\
\hline & "balanced" (calm activity) & Small \\
\hline & "rutters" (continuation) & None \\
\hline \multirow{4}{*}{$\begin{array}{l}\text { K.S.Camerona and } \\
\text { R.E.Quinna }\end{array}$} & "clan" & Big \\
\hline & "hierarchy" & None \\
\hline & “exhortation" & Small \\
\hline & "market" & Small \\
\hline \multirow{4}{*}{ Cz. Sikorski } & "domination" & small \\
\hline & "rivalry" & None \\
\hline & "cooperation" & Partial \\
\hline & "adaptation" & Big \\
\hline \multirow{5}{*}{$\begin{array}{l}\text { Organizational cul- } \\
\text { tures of the chosen } \\
\text { popular conceptons } \\
\text { of management }\end{array}$} & TQM Culture (Total Quality Management) & Big \\
\hline & $\begin{array}{l}\text { BPR Culture (Business Proces Reengine- } \\
\text { ering) }\end{array}$ & Big \\
\hline & TOC Culture (Theory of Constrains) & Big \\
\hline & LO Culture (Learning Organization) & Big \\
\hline & $\begin{array}{l}\text { Traiditional culture - „mass organization of } \\
\text { manufacturing” }\end{array}$ & None \\
\hline
\end{tabular}

ORGANIZATIONAL CULTURE

Piotr Walentynowicz

Table 1.

Convergence of the features of Lean organizational culture with other types of organizational cultures enhanced in literature of the subject

Source: own study on the basis of Czerska, 2003a; Sikorski, 2006; Zbiegień-Maciąg, 2005; Cameron and Quinn, 2003; Irani, Beskese, Love, 2012; Goldratt, 2007; Grajewski, 2003; Senge, 2003; Womack, Jones, Ross, 2008; Research on organization's culture, 2013. 
LEAN

ORGANIZATIONAL

CULTURE

Piotr Walentynowicz

Table 1.

Continued

\begin{tabular}{lll}
\hline $\begin{array}{l}\text { Author of } \\
\text { classification }\end{array}$ & Type of organiational culture & $\begin{array}{l}\text { Level of accordance with } \\
\text { Lean organizational } \\
\text { culture }\end{array}$ \\
\hline Consulting & "innovation's culture" & Big \\
\cline { 2 - 3 } $\begin{array}{l}\text { company" } \\
\text { Solutions" }\end{array}$ & "tasks' culture" & Partial \\
\cline { 2 - 3 } & "processes' culture" & Partial \\
\hline
\end{tabular}

The Lean organizational culture is a type of culture accompanying the mechanisms of Lean organization's functioning [3]. In practice actually, it never appears in its own right (Shah, Ward, 2003). It is an effect of implementation of Lean Management concept in the companies and managing them in a Lean style. The wrong belief is commonly known that Lean organizational culture equals organizational culture of Japanese companies. Nothing further from the truth [4].

There is a connection between the features of this culture and the Japanese society culture but not a direct one (Tomański, 2011). The model of Lean organizational was worked out in a flow of development of an organizational culture in Toyota company for many years (from the 40's to late 70's of age XX) (Liker, Hoseus, 2009). In Toyota or other Janapese companies in further years (Honda, Mazda, Panasonic, Sony, Kawasaki) and then based and developed in a flow of diffusion of the knowledge and using Lean Management in the companies other than Japanese ones (NUMMI,United Technologies, Wiremold, Danaher, Porsche, Scania, Unipart, Dell, Ikea and others). Therefore, possibility of applying Lean Management and creation of Lean organizational culture should not be associated with the enterprises and culture of Far East [5].

There is a connection of the features of this culture with the Japanese society culture but not a direct one (Tomański, 2011). The model of Lean organizational was worked out in a flow of development of an organizational culture in Toyota company for many years (from the 40's to late 70's of age XX) (Liker, Hoseus, 2009). In Toyota or other Janapese companies in further years (Daihatsu, Honda, Mazda, Kawasaki, Sony, Panasonic, Denso) and then based and developed in a flow of diffusion of the knowledge and using Lean Management in the companies other than Japanese ones (NUMMI,United Technologies, Wiremold, Danaher, Porsche, Scania, Unipart, Dell, Ikea and others). Therefore, possibility of applying Lean Management and creation of Lean organizational cultute should not be associated with the enterprises and culture of Far East.

While analyzing the features of Lean organizational culture in compliance with the criteria of Ch. Hampden-Turner and A. Trompenaars (Sikorski, 2006, p. 6) it should be noticed that Lean organizational culture is disposed on universalism with no elements of particular attitudes appearing in practice (even among the top 
management). In a whole organization, deductive thinking predominates (analysis and dwelling on the problems) but it does not resign from inductive thinking (synthesis), particularly in a frame of strategy and making decision by the top management.

Lean culture is disposed on a collective way of acting, problems' solving and submitting to norms and standards of the organization. Inner locus of control but assertive one and in a consensual form predominates in attitudes of the units; on the other hand the objectives and way of organization's performance are determined mainly in the external way but a rational one (controlled by the market). Synchronization of the activities happens from the bottom and automatically (e.g. by means of kanban system), but pace and order of the activities as well as structure of the processe are the results of reaction from the signals coming from the market in a natural way.

Fastness of reaction for the needs of environment is the autotelic objective in this culture. Achieving position prevails on gaining it. Empowerment rules and decision-making participation resulting from respect of the equality and justice in social relations are broadly used. Respecting hierarchy which facilitates and increases the efficiency of ensuing from different kinds of roles in the institution is also important. The characteristical way of thinking and acting in this organizational culture are also long-term orientation and small distance of authority (according to the criteria of G. Hofstede, 2000).

In respect of volume limitations, the wider chatacteristics of Lean organizational culture's features is presented in Table 2.

\begin{tabular}{|c|c|}
\hline $\begin{array}{l}\text { 1. Attitude and } \\
\text { behaviour of } \\
\text { management } \\
\text { personnel }\end{array}$ & $\begin{array}{l}\text { Attitude and behaviour of management personnel } \\
\text { 1. Real leadership (participating and task-oriented style of manage- } \\
\text { ment) } \\
\text { 2. Kindness and trust towards the subordinates } \\
\text { 3. Taking the decisions on the basis of the facts (information the most } \\
\text { often personally collected in gemba) } \\
\text { 4. Active participation in gemba ,life” and the improving project in the } \\
\text { organization } \\
\text { 5. Process, system, marketing and strategic way of thinking and per- } \\
\text { ception of the organization } \\
\text { 6. Consequent emphasis on permanent development of the employees } \\
\text { and organization (for ex ample via MBO Or Hoshin-Kanri) } \\
\text { 7. Motivating in a positive way by empowerment and respect but } \\
\text { simultaneously the consequent assesment of the results } \\
\text { 8. Little distance towards the authority } \\
\text { 9. Model of business thinking ,win-win” }\end{array}$ \\
\hline
\end{tabular}


LEAN

ORGANIZATIONAL

CULTURE

Piotr Walentynowicz
1. Attitude and behaviour of management personnel (continued)

Attitude of middle and lower management

(as above and additionally:)

10. Collectiveness dominates in realizing tasks and solving problems

11. Shaping behavours by positive own ex ample (particularly towadsthe activities of pro-qualitative charakter, anty muda)

12. Standardising management work

13. Significant participation of work in gemba and for gemba

14. Immediate problem solving

15. Encouraging subordinates (or even demanding from them) to co-participatein solving problems, to implement organizational innovations, to learn and develop individually

1. Open, positive attitude towards experiments and novelties

2. High level of decentralization of decisive entitlements in a range of ways of improvement and development and own job positions and organizational units

3. Creating helping conditions for the employees for generating and implementing innovations (inter alia

2. Attitude towards novelties, experiments and risk wheels of quality, kaizen projects and renumerating them for it)

4. Immediate verification in practise the proposed ideas and implementing them for ever if they are useful

5. Efficient and immediate system of feedback information on the given proposals

6. Avoiding too big risk but also behaviour which is toodefensive

7. All employees of the company have right for experimenting and learning by mistakes - making mistakes but only once; being supervised by superior, sensei (Japanese: master)

1. It is allowed and even demanded (individual and in form of fomalized systems)

2. Freedom in a range of implementing pro-effective innovations at own job position in agreement with

3. Engagement of executive personel in improving actions
Table 2.

Continued superior

3. Complete freedom in reporting proposals of improvement towards to other areas of organization

4. Rewarding for pro-innovative activity

5. Employees are willing for participation in generation innovations and implementing changes which are of pro-effective character from the bottom 
1. Partnership

2. Complete acceptance of own roles and efficient ensuing from them

3. Little distance of power

4. Cooperation based on mutual respect and trust

4. Relations: superor subordinate
5. Collective work, consultation or team decisions' making and organizational problems' solution

6. Positive organizational atmosphere

7. Superior coach, mentorteacher (particularly in a ranfe of methods and Lean culture) but also setting out to gaining knowledge from own employees

8. Employee with wide decisive rights but respecting superior's opinion

1. Processing configuration of particular organizational sections facilitating communication and cooperation

2. Basic processes are most important in the organization (they create added value for client in a direct way - gemba)
5. Relations between organizational units

6. Communi-cation in organization

3. Managers and employees of functional sections undertand their servient role towards sections and gemba processes

4. Cooperation based on mutual respect and trust, positive organizational atmosphere

5. Lack of deeper conflicts on the background of resources division, conflicts are solved fast and efficiently

6. Informal groups share organizational objectices and support their realization

1. Lack of barriers in communication and cooperation of particular sections in organization

2. Processing configuration of particular organizational sections facilitates communication and cooperation

3. Short and first of all direct informational ways (in a hortical and vertical way)

4. Short, clear and legible reports, communicates limited only to essential ones (e.g. A3 report)

5. The employees are willing to share the information and cooperate

6. Visual form of communication dominates

1. Managers' duty is to find the problems and potential problem and organizing their solving in a creative way, anticipating (with participation of the subordinates in this process)

2. Employees often take part in problem solving, they are also willing to report observing problems

7. Attitudes towards oranizational problems
3. Majority of problems are solved in a collective way, by formalized methodology

4. Source reasons of the problems are searched and eliminated (not symptoms)

5. Not hiding the problems. Solicitous exchange in the subject of way of solving particular problems and using help of the other in organization and outside 
LEAN

ORGANIZATIONAL

CULTURE

Piotr Walentynowicz

8. Team work

9. Source of authority

10. Attitude towards various points of views

11. Attitude towards oranizational changes

1. Collective work are the basis of making duties in gemba and conceptual work

2. Collective motiviation, rewarding and celebration of the results

3. Thanks to collective work, there is high effectiveness of using the employees and flexibility of organization. Employees with universal competences take part in work of many different teams (job rotation, job enlargement)

4. Employees and managers are willing to work in teams, also interdiscipline ones and with the partners from the other sections

1. Real authority and respect towards superior appointed for this position on the basis of their competences

2. Wide spectrum of using material and non-material ways of motivation next to attractive economic-financial instruments of motivation for results

3. Predomination of alluring over compulsory conditions, compulsory instruments of motivation applied first of all in a form of prevention

4. Free career path of management personnel, preferable internal sources of superiors

1. "Strength in variety and interdisciplines"

2. Management tolerates and even encourages for statements of different character

3. Heading to consensus and working out optimal organizational solutions by multilateral agreements (nemawashi)

4. Management is willing to listen to point of view of the other people (also subordinates). They respect other people's opinion

5. Culture of admitting to mistakes, changes of opinions with no shame ig member of organization is not right

1. Changes are treated as a normal phenomenon in the organization as a chance of its development

2. Demanded changes of pro-developing character. Possibility of reporting the proposals of this type of changes by every employee if she/he notices such a chance.

3. Changes which are fictitious are not conducted

4. Engagement in implementing organizational changes of prodeveloping character a re duty of every employees (the same as comprehensive elimination of muda from the organization)

Table 2.

5. Reluctance towards changes on the minimum level or do not appear 
1. Organization also as a place of earning money but first of all as a place of self-realization and development

12. Attitude
towards
organization and
meaning of work in
value hierarchy

13. Attitute towards learning and development
2. Work and organizational roles as source of satisfaction and fulfilling ambitions

3. Total symbiosis between employees and organization (employees understand this connection in market economy and by common effeorts desire to maintain and develop their place of work)

4. Loyality and commitment as one of the most important values in work environment

5. Institution returns the employees their commitment and gives back by fair conditions of work and renumeration

1. The base for organizational growth is qaulity development

2. Growth of organization is treated as using market and competitive advantages and not "at any price"

3. Attitute for learning and development of the employees, encouraging them

4. Expanded internal programmes of trainings and development (first of all for Lean and Continuous Improvement)

5. Superior is a teacher of positive practice and rules of functioning in organization

6. Learning in practice and through a good practice (kaizen, quality wheels, on the job training, knowhow and experience exchange, creativeness and collective synergy)

7. Internal and external benchamarking is willingly applied

1. High level of standardization of the activities and processes in the organization, including work (so called favouring bureaucracy)

2. Respected and obeyed standards

14. Obeying organizational standards
3. If there is such a chance, possibility of reporting proposals of standard s' improvement

4. Low level of formalization in a range of management and organizational regulations (so called suppressing bureaucracy)

5. Maximum amoint of standards and organizational regulations presented in a clear, legible way and in a form of visual communicates
Table 2. Continued 
LEAN

ORGANIZATIONAL

CULTURE

Piotr Walentynowicz

1. Obeying norms and pro-quality procedures is on a very high level

2. The employees' caring for quality of the results of main and auxiliary processes in organizarion is ine of the most important objective

3. The employees treat quality seriously and not in a fictitious way

4. Attitute on prevention, control built in a process (and not ex post) - self-checking, "quality at first time", no defect can be passed to next position and for next section, jidoka, PokaYoke solutions and etc.

5. Constant improvement of quality of goods, services and level of customer service

1. All managers and employees in organization know and obey the rulet that in market economu, the company exists only thanks to its clients

2. Added value for a final customer is the highest category for which "organization life goes round"

3. Added value for the final client is not only high quality but also short time of delivery and attractive prices precisely adjusted to his/her needs towards goods or services

16. Attitudes towads the clients
Table 2.

Continued

4. Determined and broadly used concept of organizational standards of customer service

5. Determined, understood and respected concept of internal client

6. Involving clients in process of designing/improving company's offer

7. Help for clients (particularly business ones) in detailed determining their needs and better adjusting company's offer to these needs

8. In marketing giving the clients only these promises which are possible to be kept

1. Partnership attitude

2. Long-term orientation

17. Attitude towards business partners
3. Mutual help in solving problems and improving activities (Lean partner of ten helps non-Lean partner

4. Mutual respect and aiming on consensus within the bilateral relations

5. Facilitating performance of business partner (e.g. through stable orders resulting from production leveling)

1. CSR policy is most ofeten written $n$ the bqsic profiles of activity.

18. Attitude

2. CSR is not onlyy declared but actually realized

towards ecology and interested parties of the organization
3. Taking care for ecology,, material savings and energy and also respecting natural environment is essential value not only as a whole organization but also on each job position 
1. Criteria of results evaluation first of all qualititative (customer satisfaction, amount of the defects, OEE and correction of these indicators)

\section{Criteria of evaluation of organization's and participants' effectiveness}

\section{Institutional results of a given type of organizational culture}

2. Work in a rhythm of customers' orders (yes time), quanitity does not count so much

3. Quantitive increase and increase of economic-financial results is essential but first of all as a consequence of quality aspiration and customers satisfaction

4. Applying Activity-based costing (ABC)

5. Quantity and quality of implemented organizational improvements are important

6. Criteria of evaluation in SQDC category (security, quality, delivery, cost)

1. Lean organizational structure (in a process dimension with limited number of management positions and auxiliary sections)

2. Clean, orders and safe work environment $-5 \mathrm{~S}$ (bot at the office as gemba)

3. Low stock at input, low stock in production process and low stock at otput, warehouses organized most often in a form of supermarkets

4. Short time of production processes performed most often in a form of one piece flow

5. Shorter terms of goods delivery or services for the customers than in a traditional forms of manufacturing

6. Production processes dedicated to particular groups of products (value stream)

7. High ratio of current assets

8. Short time of retooling machines and devices providing higheroperational flexibility than in a traditional system

9. Practically uncommon production defects, high quality of goods and services

10. Great care for production equipment (ona prevetion basis) and high level of its reliability)

11. Positive vibe and work atmosphere

12. Satisfied and engaged in their duties realizations' employees

13. High level of market competetiveness of the company

14. Good economy-financial results (better than average in a line of business)
Table 2.

Continued

The above listing was worked out on the basis o literature studies and empirical research of the author. The critieria of the phenomenon's description was set within using the measurement sheet of pro-efficient and pro-effective organizational culture of M. Czerska (2003b, pp. 551-552) and the description of features of traditional and process organizational culture by P. Grajewski (2003, pp. 242-256). Assumedly, it aims to help the top and middle management to better understand the objectives which they should strive for in 
Piotr Walentynowicz a transformation process of the organizational culture while implementing Lean Management.

\section{The way of shaping the Lean organizational culture}

Apparently, correction of organizational culture in a process of Lean Management implementation can be done basing on a model which is proposed by followers of so-called concept of "course correction" (Hofstede, 2000; Davis, 1984; Kilmann and in., 1988; Dyer jr., 1985; Czerska, 2003a; Skalik, 2012). This model in outline consists of the following stages:

1) Formulating the strategy of company's development (here Lean Management),

2) Defining target organizational culture,

3) Diagnosing exisitng organizational culture,

4) Comparing the existing and target organizational culture,

5) Working out the project of changing the organizational culture,

6) Implementing the project of changing the organizational culture,

7) Control.

However, this attitude in case of so dificult, sophisticated and long-term process which Lean transformation is, may not succeed. That is why the practicioners and theoreticians of Lean Management delegate to realise this process in more incremental and pragmatic way (Balle 2008; Balle, Balle, 2012; Shook, 2010; Mann 2005; Liker 2005; Piątkowski, 2005; Piątkowski 2009; Byrne, 2013). In Lean Management changes of organizational culture are made first of all by the active involving the employees in the actions which are of organization's transformating character (participation in Lean projects, 5S and kaizen on own job position, active participation in TPM and SMED programmes and suggestions systems) during which the employees on the basis of own experience become convinced that Lean does not consist in harder, longer or more exhausting working but in working in a wiser way [6].

Additionally, it is made in a pilotage way so that positive effects may firstly come into existence in some areas of the organization and then in a facilitating way spread out for the other ones. Obviously, all the aspects mentioned above must be preceded by suitable trainings: general ones (e.g. of Lean Management role in modern companies - in a form of Lean Manufacturing simulation best) and detailed ones (regarding the essence of Lean organization's particular tools or solutions). The author's research indicates that line employees are more engaged in these trainings and willing to fast introducing the particular Lean solutions for own organization.

On the other hand, bigger barrier in this process is lower and middle management. Lean conception disturbs their previous "calm" life in the organization and breaks traditional solidified until now rules of their acting. Some 
people think that it also decreases their power and reduce their authority - but only in accordance to traditional way of interpreting these issues. One more serious danger is added - liquidation of a part of management positions. That is why changing these aspects among the company's management is the bigger problem than changing awareness, mentality and attitude of line employees in a process of Lean Management's implementation.

Here, we reach to the essence of the problem. Lean organizational culture is first of all created by changing the way of management in a company and through so-called appropriate "example from the top" (Oakland, 2011). Therefore, the key for the success in this process is basically a successful change of attitudes, mentality and styles of top management's performance. If it is impossible to be done in a real way the Lean organization is not possible to be created.

In the initial period, the enforcement of some behaviour from the area of new cultural standard is necessary, otherwise Lean Management could not be propagated (Skalik, 2006, pp.149-153). Deviation from the norms can not be tolerated because it will be demotivating for the others. That is why especially reluctant employees should be removed form the company (Womack, Jones, 2008, pp. 418-419; Henderson, Larco, 2002, pp. 93-94 and next; Morfopoulos et al., 2009, p. 101). But after some time, if the employees see the sense that the implemented solutions facilitate their work and result in higher renumeration, they are willing to join the activites of Lean character and simultaneously they correct their attitudes and organizational behaviours.

The model prepared by M. Ballé can be helpful in shaping Lean organizational culture (Ballé, 2008, p. 4 and next):

1) To understand differences in a culture.

2) To diminish differences in a culture.

3) To eliminate differences in a culture.

The ways of this model's points 2 and 3 realization were presented shortly above. However, the most important from the point of view of the level of succeding this process is point 1 , particularly among top management whose tasks is to perform a leading role in this process. Understanding differences in a culture from one side happens through the exact understanding of the Lean Management essence and cultural background of Lean organizational culture and then through diagnosis of actual company's organizational culture and estimation of the size of its cultural gap. Because until now the prepared tools of organizational culture's diagnosis most often refers to its traditional types and divisions (e.g. K.S. Qameron and R.E. Quin's; L. Zbiegień-Maciąg's, or “Solution's” company) and the sheets of the level of Lean concept implementation treat the issued of Lean organizational cultures too generally (e.g. M. Piątkowski's, A. Sharma and G. Hourselt's, "TBM's" consulting company) and so far prepared tools of organizational culture measurement are not perfect (for example Jenei at al. lub 
LEAN

ORGANIZATIONAL

CULTURE

Piotr Walentynowicz

Table 3.

Proposed sheet of Lean organizational culture's diagnosis [7]

Source: own elaboration on the basis of Czerska, 2003b, pp. 551-552; Grajewski, 2003, pp. 242-256.
The Lean Way Consulting), the author decided to prepare own questionnaire of the analysis and diagnosis of this culture. This questionnaire is presented in Table 3 .

\section{Criterion}

Rating

$\begin{array}{lllll}1 & 2 & 3 & 4 & 5\end{array}$

1. Attitude of top management

2. Attitude of middle and lower management

3. Attitude towards novelties, experiments and risk

4. Engagement of executive personel in improving actions

5. Relations: superior - subordinate

6. Relations between organizational units

7. Communication in organization

8. Attitude towards organizational problems

9. Team work

10. Source of the authority

11. Attitude towards various points of views

12. Attitudes towards organizational changes

13. Attitude towards organization and meaning of work in value hierarchy

14. Attitude towards development and learning

15. Obeying organizational standards

16. Care for quality (of the effects of own work, foods and services)

17. Attitude towards clients

18. Attitude toward business partners

19. Attitude towards ecology and interested parties of the organization

20. Criteria of evaluation of organization's and participants' effectiveness

21. Intitutional results of a given type of organizational culture

Total

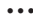

The particular criteria are rated in a range from 1 to 5. Extremely bad condition of organizational culture, inconsistent with Lean model, gets a mark 1. The indirect marks determine the size of cultural gap which should be diminished and then eliminated in Lean process transformation. However, the ideal situation being reflection of model backround of this culture gets a mark 5 .

This tool can be used by the members of the top management or Lean coordinators implementing this concept in a company. It can also be used on trainings regarding Lean organizational culture directed for middle and lower management. If those people are to play the leading role in Lean Management implementation process, to achieve successful implementation they have 
to understand exactly in what the differences between traditional and Lean organizational culture lie (and of course change their attitudes and behaviours). In this case, Table 2 should be the integral part of the prepared questionnaire.

\section{Summary}

Lean organizational culture is an example of a positive organizational culture. It is a result of using the concept of Lean Management in a company but only on the high level of professionalism. Not all the enterprises have to strive for achievement of the same condition as it was presented in this article (similarly as not all the enterprises must follow the path of Lean Management), nevertheless as the results of many empirical research proves it is the most useful for the present company (Walentynowicz, 2013, p. 94-103). The above article presents what features has the Lean organizational and how it should be created.

Basing on the above aassumptions, in the article, the essence of Lean organizational culture as a new, so far weakly expose, particularly in Polish literature regarding types of organizational culture, together with authorial tool of its measuring, is presented. Assumedly, this tool aims to help the agents of changes in the companies which decided to implement Lean Management to evaluate the level of organizational culture present in those companies, to estimate the size of cultural gap, to plan the way of decreasing the gap and as a consequence to eliminate it (according to M.Balle model). As it results from the author's research, success in Lean Management implementaton first of all depends on whether the appropriate organizational is able to be created and on what level in the company implementing this conception.

\section{Notes}

[1] "Lean Management is a concept derived from the Toyots company's way of thinking and performing which is based on using such ways of the company's performance to achieve the best effects of the its activity with the smallest input in a given technical and organizational conditions. In this concept, it is basically achieved by many-sided elimination of all kinds of acts of waste (muda - in Japanese), which the operating entities try to eliminate not only from the production systems and in a further perspective from the whole organization, but also from the whole logistic chain connected with the company's performance (deliverers of I, II and further categories, trade partners, cooperative organizations, etc.)" (Nogalski, Walentynowicz, 2009).

[2] This research is conducted in years 2008-2011 inter alia with the method of participating observation in 10 big and medium production companies operating in Poland.

[3] More on Lean organization the author writes in: (Walentynowicz, 2011).

[4] In initial period of their development, in Japan, just after II World War, Toyota or other Japanese companies faced the greater culture problems and traditional way of people approach to work than nowaday's average American, European or Eastern European company (Shimokawa, Fujimoto, 2011, p. 137-138; Womack, Jones, 2008, pp. 357-361 and the next).

[5] The cases mentioned above convince us about it as wellthe cases of succesfful Lean transformation of the enterprises in Poland - e.g. WSK PZL Rzeszów, WSK PZL Mielec, Prat\&Whitney from 
LEAN

ORGANIZATIONAL

CULTURE

Piotr Walentynowicz
Kalisz, Franke Foodservice Systems Poland Gdynia, Klose SA, Scania Production Słupsk SA, ZPT Kruszwica SA, GATX Rail Poland and others.

[6] The idea of work organization in a frame of Lean Management can be compared to the ,green wave" in road traffic but in opposition to road traffic, it succeeds only in Lean Management.

[7] Original of this questionnaire was presented in: (Walentynowicz, 2013).

\section{References}

Ballé, M., Ballé, F. (2012), Company's Director as Lean Manager. Novel About Company's Transformation, LEIP Publisher, Wrocław.

Ballé, M. (2008), "Lean Transformation”, seminar materials of VIII International Conference of Lean Manufacturing, LEIP, Wrocław.

Byrne, A. (2013), How to Revolutionize a Company Thanks to Lean Management, LEIP Publisher, Wrocław.

Cameron, K.S., Quin, R.E. (2003), Organizational Culture - Diagnosis and Change, Oficyna Ekonomiczna Publisher, Kraków.

Czerska, M. (2003a), Culture Change of Organization. Challenge for Modern Manager, Difin, Warszawa.

Czerska, M. (2003b), “Condition of culture in business organization”, Skalik, J. (Ed.), Behaviours of Organization Towards Critical Phenomena, Cornetis, Wrocław, pp. 547-565.

Davis, S.M. (1984), Managing Corporate Culture, Ballinger Publishing, Cambridge, UK.

Dyer, W.G. jr (1985), "The Cycle of Cultural Evolution in Organization”, Kilmann R.H., Gaining Control, of the Corporate Culture, Josey-Bass Publishing, San Francisco, Clifornia.

Grajewski, P. (2003), The concept of the structure of the process organization, Dom Organizatora Publisher, Torun.

Goldratt, E.M. (2007), Objective I: Excellence in manufacturing, MINT Books Publisher, Warszawa 2007.

Haffer, R., Glińska-Neweś, A. (2013), "Positive potential of organization as a determiner of a company's success. Case of Poland and France", Zarzqdzanie i Finanse, Vol. 11, No 4/1, pp. 91-100.

Henderson, B.A., Larco, J.L. (2002), Lean Transformation: How to Change Your Business into a Lean Enterprise, The Oaklea Press, Richmond, Virginia.

Hofstede, G. (2000), Cultures and Organization, PWE Publisher, Warszawa.

Irani, Z., Beskese, A., Love, P.E.D. (2004), “Total quality management and corporate culture: constructs of organisational excellence", Technovation, No. 24, pp. 643-650, available at: http://faculty.mu.edu.sa/public/uploads/1360858864.9557organization al\%20cult183.pdf (accessed 16 February 2014).

DOI: 10.1016/S0166-4972(02)00128-1

Jenei, I., Imre, N., Losonci, D. (2011), "What is lean culture - and how to measure it?", materials of $18^{\text {th }}$ International Annual EurOMA Conference, Cambridge, UK, available at: http://www.uni-corvinus.hu/index.php?id=41618\&type=p\&file_id=264 (accessed 15 October 2013). 
izing Organizations for a Competitive World, Josey-Bass Publishing, San Francisco, Clifornia.

Kotter, J.P., Heskett, J.L. (1992), Corporate Culture and Performance, MacMillan International, Oxford, UK.

Liker, J. (2005), The Toyota Way. 14 Rules of Management of a Worldwide Leading Producing Company, MT Biznes Publisher, Warszawa.

Liker, J., Hoseus, M. (2009), Toyota Culture, MT Biznes Publisher, Warszawa.

Mann, D.W. (2005), Creating a Lean Culture. Tools to Sustain Lean Conversion, Productivity Press, New York.

Morfopoulos, P., Jóźwiak, G., Malinowski, R., Pastwa, M., Bąk, K. (2009), "Practical knowledge of successes and mistakes while implementing Lean in two companies", Koch, T. (Ed.), IX International Conference of Lean Manufacturing, conference materials, LEIP, Wrocław, pp. 93-113.

Nogalski, B., Walentynowicz, P. (2009), "Help in raising competetiveness of business partners as one of fundamental background of Lean Management concept", Juchniewicz, M. (Ed.) Factors and Sources of Competitive Advantage, UWM Publisher, Olsztyn, pp. 33-44.

Oakland,J.(2011)“Leadershipand policy deployment. ThebackboneofTQM”,TotalQuality Management \& Business Excelence, Vol. 22, Issue 5, pp. 517-534, available at: http:// www.tandfonline.com/doi/full/10.1080/14783363.2011.579407\#.UwTmJVKPJd g (accesed 14 February 2014). DOI: 10.1080/14783363.2011.579407

Piątkowski, M. (2005), "Lean Manufacturing implementation in Poland”, Koch, T. (Ed.) V Lean Manufacturing Conference, conference materials, WCTT, Wroclaw Technical University, Wrocław, pp. 14-30.

Piątkowski, M. (2009), "Management of Lean Manufacturing implementation - back do the base", seminar materials of IX International Conferences of Lean Manufacturing Conference, LEIP, Wrocław.

Senge, P. (2003), The fifth discipline. Theory and practice of learning organizations, Oficyna Ekonomiczna, Kraków.

Shah, R., Ward, P.T. (2003), "Lean manufacturing: context, practice bundles, and performance", Journal of Operations Management, No. 21, pp. 129-149, available at: http://www.carlsonschool.umn.edu/assets/101192.pdf (accessed 15 February 2014). DOI: 10.1016/S0272-6963(02)00108-0

Sharma, A., Hourselt, G. (2006), The Antidote. How to Transform Your Business for the Extreme Callenges of the $21^{\text {st }}$ Century, Managing Times Press, Durham, North Carolina.

Shimokawa, K., Fujimoto, T. (Ed.) (2011), Lean Management. Birth of Management System, LEIP Publisher, Wrocław.

Shook, J. (2010), "Lean leadership. Balancing process and people", Koch T. (Ed.) X International Conference of Lean Manufacturing, conference materials, LEIP, Wrocław, pp. 14-39.

Sikorski, Cz. (2006), Organisational Culture, C.H. Beck, Warszawa.

Skalik, J. (2006), "Creativities of employees as a source of reinforcement key competences in organization”, Krupski, R. (Ed.), Strategic Management. Resources Picture, „Prace 
LEAN

ORGANIZATIONAL CULTURE

Piotr Walentynowicz
Naukowe Wyższej Szkoły Zarządzania i Przedsiębiorczości”, series: „Zarządzanie i Marketing”, Wałbrzych, pp. 147-154.

Skalik, J. (2012), ,Cultural determinqnts of economic organizations' growth and development", in: Mikuła, B. (Ed.) History and perspectives of the studies on management, Wydawnictwo Fundacji Uniwersytetu Ekonomicznego w Krakowie Publisher, Kraków, pp. 123-130.

Stankiewicz, M.J. (Ed.) (2010), Positive potential of organization. Introduction for the useful theory of management, Dom Organizatora Publisher, Torun.

The Lean Way Consulting (2013), Lean Culture Introduction, http://www.slideshare.net/ ankit114/lean-culture-introduction, (accessed 12 October 2013).

Tomański, R. (2011), Tatami Versus Chairs. About Japanese and Japan, Warszawskie Wydawnictwo Literackie Muza SA Publisher, Warszawa.

Walentynowicz, P. (2011), "Lean organization as an answer of the company for challenges of contemporary environment", Oniszczuk-Jastrząbek, A. (Ed.) Company in a Global Environment. Development in Conditions of Economy Instability, Publishing House of The Gdansk University Development's Funds, Gdańsk, pp. 75-102.

Walentynowicz, P. (2013), Conditions of Efficiency of Implementing Lean Management in Production Companies in Poland, Publishing House of The Gdansk University, Gdańsk.

Womack, J.P., Jones, D.T. (2008), Lean Thinking. BanishWaste and Create Wealth in Your Company, ProdPress Publisher, Wrocław.

Womack, J.P., Jones, D.T., Roos, D. (2008), The Machine That Changed the World, ProdPress Publisher, Wrocław.

Wróblewska,A., Kaleta,J.(2013), “Organisationalcultureresearch”, InternetManager, available at: http://www.im.org.pl/php/index.php?id=artykul\&d=Zarządzanie Kadrami\&p =artykuly/zarz-kadrami/bad-kul-org.htm (accessed 10 October 2013).

Zbiegień-Maciąg, L. (2005), Culture in Organization. Identification of Cultures of Known Companies, Wydawnictwo Naukowe PWN Publisher, Warszawa. 